\title{
Memória da educação e da escola lassalista: um acervo de fontes orais em construção (2002-2016)
}

\author{
Memory of education and of the Lassalian School: a oral sources \\ collection in construction (2002 - 2016)
}

Memoria de la educación y de la escuela Lasaliana: una colección de fuentes orales en construcción (2002-2016)

Cleusa Maria Gomes GraebiN ${ }^{1}$

\section{Resumo}

O objetivo deste trabalho é apresentar a construção do acervo de fontes orais denominado "Projeto Memória Lassalista", o qual integra as coleções de documentos sob a guarda do Museu Histórico La Salle (MAHLS), do Unilasalle Canoas. Na busca de atender aos pressupostos para a montagem deste Dossiê, também, são tecidas considerações sobre: o depositário da coleção; as bases históricas e teóricas do Projeto; a sua constituição e operacionalização e possibilidades de utilização; as perspectivas para o futuro do Projeto; e as complexidades e desafios em relação à produção, tratamento, preservação e socialização de acervos orais com narrativas sobre educação e escolas.

Palavras-chave: Projeto Memória Lassalista, História das instituições escolares, Memória, História Oral, Acervos de fontes orais.

\footnotetext{
${ }^{1}$ Doutora em História pela Universidade do Vale do Rio dos Sinos. Coordenadora e professora do Programa de Pós-Graduação em Memória Social e Bens Culturais e professora do Curso de História do Unilasalle Canoas. Coordenadora do Museu e Arquivo Histórico La Salle. Editora da Mouseion Revista Eletrônica. E-mail: cleusa.graebin@unilasalle.edu.br; cleusamggr@gmail.com
} 


\section{Abstract}

The objective of this article is to present the construction of the construction of the oral sources collection called "Lasallian Memory Project", which integrates the collections of documents under the guard of the "Museu Histórico La Salle" (MAHLS), from Unilassale Canoas. In the search to meet the theoretical foundations for the assembly of this Dossier, considerations are elaborated about: the depositary of the collection; the historical and theoretical bases of the Project; it's constitution and operationalization and usage possibilities; the perspectives for the future of the Project; and the complexities and challenges regarding the production, treatment, preservation and socialization of oral collections containing narratives about education and schools.

Keywords: Lasallian Memory Project, History of the educational institutions, Memory, Oral History, Oral Sources Collections.

\section{Resumen}

El objetivo de este trabajo es presentar la construcción de la colección de fuentes orales que se denominan "Proyecto Memoria Lasaliana", que integra las colecciones de documentos en poder del Museu Histórico La Salle (MAHLS), del Unilasalle Canoas. En la búsqueda por atender a los presupuestos para el montaje de este Dosier, también se hacen consideraciones sobre: el depositario de la colección; las bases históricas y teóricas del proyecto; su constitución y operacionalización y posibilidades de utilización; las perspectivas para el futuro del Proyecto; y las complejidades y desafios en relación a la producción, tratamiento, preservación, y socialización de colecciones orales con narrativas sobre historia y escuelas.

Palabras clave: Proyecto Memoria Lasaliana, historia de las instituciones escolares, memoria, historia oral, colecciones de fuentes orales. 
Ver uma coisa é não ver outra. Narrar um drama é esquecer outro.

(Ricouer, 2007, p. 459)

\section{O Museu Histórico La Salle (MAHLS)}

A partir de 1996, iniciou, no Centro Universitário La Salle (Unilasalle Canoas), um movimento para estudo e preservação dos bens culturais materiais e imateriais do Instituto dos Irmãos das Escolas Cristãs ${ }^{2}$, cujos membros são conhecidos no Brasil como Irmãos Lassalistas. Dissertações de mestrado e teses de doutorado foram elaboradas, por meio de projetos de pesquisa que visavam a desvelar o universo da educação, da rede de escolas e do ensino superior lassalista, discutindo a formação de professores, a pedagogia, metodologias e projetos político pedagógicos. Paralelamente, fez-se um trabalho de levantamento de documentos nos arquivos escolares, recursos materiais didáticos e mobiliários escolares de diferentes tempos, disponíveis nas unidades educativas, a fim de se ter fontes para pesquisa.

A quantidade de objetos e documentos preservados por docentes, discentes e Irmãos levou à decisão de se propor a criação de um museu e um arquivo histórico. Assim, entre 1996 e 1998, elaborou-se projeto para tal e pela Resolução $n^{0 \cdot}$ 25/98, de 21 de agosto de 1998, a Reitoria do Unilasalle aprovou o Regulamento do Centro de Pesquisa e Exposição da Memória e Educação Lassalista (Memorial La Salle). O início da execução do projeto deu-se em março de 1999.

O Centro de Pesquisa e Exposição da Memória e Educação Lassalistas - Memorial La Salle - nasceu como órgão vinculado à Reitoria do Centro Universitário La Salle e seus objetivos consistiam em: estabelecer espaço privilegiado para pesquisa e estudo sobre o Instituto dos Irmãos das Escolas Cristãs; guardar, organizar, preservar e divulgar os acervos documentais sobre São João Batista de La Salle, a educação e a memória lassalista. Sua ação baseou-se na concepção de que o patrimônio cultural lassalista, para além da sua preservação, deveria passar pela problematização do seu próprio sentido, analisando-se seu processo de constituição e sua historicidade, mapeando as relações entre o visível (objetos/documentos) e o invisível (o mundo que aqueles representavam). Fundamentaram-se as ações no entendimento da "[...] radical impossibilidade do passado ser novamente presente, como quando ele era vida e experiência" (GUIMARÃES, 2010, p. 48). Os objetos escolares e documentos foram os protagonistas do processo de musealização ressignificados no memorial enquanto memória lassalista.

\footnotetext{
${ }^{2}$ O Instituto dos Irmãos das Escolas Cristãs, cujos membros são conhecidos como Irmãos de La Salle ou Irmãos Lassalistas, é uma congregação de religiosos leigos, voltada para a educação, fundada em 1684 na França, por João Batista de La Salle. Da França, a Congregação espalhou-se pelo mundo, estando presente hoje em todos os continentes. Ao Brasil, o9s Irmãos Lassalistas chegaram em 1907, estabelecendo-se em Porto Alegre, polo a partir do qual multiplicaram suas escolas pelo país.
} 
O Memorial La Salle constituiu-se em espaço patrimonial onde se passou a narrar as coleções que, de certa forma, passaram a assegurar a existência identitária lassalista, autenticando um compartilhar de ligação afetiva com o passado e um patrimônio comum. A possibilidade de perpetuar elementos pertencentes a determinado grupo social implica a referência institucionalizada à sua memória. Esta função e papel social transferiram-se para o desdobramento do Memorial em Museu e Arquivo Histórico La Salle (MAHLS) a partir de 2002. Em 2016, o Museu passa por reconfiguração, incorporando a documentação do Arquivo Histórico como coleções documentais e assumindo a identidade de museu histórico, Museu Histórico La Salle, mantendo a mesma sigla, MAHLS.

As coleções de documentos e objetos transmutaram-se, expostos no Museu ou guardados na sua reserva técnica. Possuíam uma utilidade nas relações sociais cotidianas nas escolas, mas agora, na instituição museal ganharam excepcionalidade e destaque como provas, com a memória dos lassalistas neles fixada. Transferidos de diferentes escolas, conservaram um sentido e adquiriram outro: continuaram como prova material da existência das escolas e da educação lassalista, mas também se procurou entendê-los na sua metamorfose, de artefato a objeto com memória historicamente constituída "[...] em simbiose com o poder da memória e a memória do poder, nas suas mais variadas manifestações" (RAMOS, 2010, p. 76). A partir do ato de criação do espaço de memória e das exposições, produziu-se patrimônio e ratificou-se a transmissão. Candau (2009) denomina objetos, imagens e monumentos, de sociotransmissores, os quais promovem/solicitam emoções, afetividades, imaginários compartilhados, em um trabalho de memorização. O museu é um depositário da descoberta desses objetos. Cada visita auxilia a criar patrimônio, a reforçar identidades e representações.

Nesta intencionalidade memorial, pretendeu-se fugir da narrativa laudatória, do comemorialismo, da obsessão de identidade e do esquecimento forçado. No entanto, sabe-se que mesmo estes constroem sentidos sobre o passado. Buscou-se uma "justa sensibilidade patrimonial", como aponta Candau (2009, p. 54), construindo formas internas de memórias postas em diálogo (RICOEUR, 2007). Assim, pensou-se em uma maneira de proporcionar o que se denominou de "encontro de memórias em cooperação" entre os diferentes grupos que se formaram/formam nos intramuros das comunidades lassalistas que abrangem escolas, casas de formação de Irmãos, obras assistenciais e instituições de ensino superior.

Desta maneira, ao findar o ano de 2003, elaborou-se projeto para a constituição de um acervo de fontes orais cujos documentos viessem a auxiliar na problematização, compreensão e em narrativas possíveis do processo histórico da trajetória das ações educativas, das escolas e dos próprios lassalistas no Rio Grande do Sul. Estas fontes, que trazem diferentes perspectivas de sujeitos que participaram ou ouviram falar sobre a instituição, têm contribuído tanto para a pesquisa dos artefatos musealizados, como apresentam novos questionamentos, possibilitando interpretações e novas versões sobre a educação no Brasil, tendo a instituição escolar como categoria de análise. Os testemunhos orais possibilitam apreender, como colocou Gatti Junior, elementos "[...] que conferem identidade à instituição educacional, ou seja, daquilo que lhe confere um sentido único no cenário social do qual fez ou ainda faz parte, mesmo que ela tenha se transformado no decorrer dos tempos" (2002, p. 20). 


\section{As bases históricas e teóricas do Projeto "Memória Lassalista"}

O projeto recebeu o nome de "Arquivo sonoro e visual da memória lassalista" (mais conhecido como Projeto Memória Lassalista), iniciando em 2004. Apoiou-se no contexto dos estudos sobre a história das instituições escolares, considerada como renovação temática em termos de estudos da história da educação brasileira (GATTI JUNIOR, 2002). Warde (1984), Nagle (1994), Saviani (1998) e Nóvoa (1996) já haviam discutido estudos históricos sobre a educação brasileira, as tendências historiográficas, identificando a organização da História da Educação como disciplina, atentando para a dificuldade desta em ser reconhecida como um dos domínios do campo histórico. Saviani (1998) comentava que os desafios do historiador da educação, eram variados, notadamente os que se referem aos aportes teóricos e metodológicos da História, para fundamentar e operar suas investigações. Isto, tendo em vista que a maioria dos pesquisadores que se dedicam a este domínio, não são historiadores de ofício, o que implica em dupla jornada, ou seja, percorrer o vasto canteiro da História e dar conta da dimensão histórica dos fenômenos educacionais.

Falcon (2006) também abordou sobre a ausência da história da educação no âmbito do trabalho do historiador, apontando para conjunto de obras publicadas no Brasil, discutindo tendências historiográficas entre 1976 e 1992, as quais não inseriam aquela temática. Na sequência de seu texto, comenta sobre trabalhos publicados em 1993, $1998 \mathrm{e}$ 2003 que traziam as relações entre história da educação e história cultural. O autor, apoiado em Warde (1990), comenta que a história da educação foi instituída como ciência ou como ciência auxiliar da educação, permanecendo, institucionalmente, alocada nos Departamentos ou Programas de Pós-Graduação em Educação nas universidades. Discorrendo sobre as origens das abordagens e dimensões da história da educação, coloca autores que indicam esta como disciplina de intersecção entre os campos da educação e o das ciências históricas, portanto, sem autonomia. Ainda, Falcon (2006) trata da relação entre história da educação e história cultural, com todas as implicações epistemológicas que acompanham a segunda. Afirma que:

[...] a história cultural não deveria ser apenas uma denominação ou rótulo que se aplicaria a um campo de estudos constituído de objetos e temas específicos. A ideia de atribuir uma espécie de lugar ao cultural em termos de realidade histórica, um lugar situado entre o econômico, o político e o social, talvez tenha tido sua razão de ser no começo da história cultural. Hoje, todavia, sabe-se que esse lugar não existe, assim como tampouco existe uma alocação arquitetônica que permita dizer se a história cultural está acima, abaixo, ou ao lado de outros aspectos do real. (2006, p. 336).

Assim, não se trata de mais uma disciplina entre as demais especializadas e definidas em função de determinada temática, mas um campo multi e interdisciplinar articulando temas e problemas, sem hierarquização em termos de dimensão ou espaço do real. Falcon 
finaliza suas reflexões citando Rioux (1997) indicando aportes no âmbito da história cultural: relações entre o político e o cultural, mediações e mediadores de saberes e informações, práticas culturais (sociabilidades, religião, usos e costumes, produções identitárias, memórias, entre outros), signos, símbolos, sensibilidades, enfim, “[...] como os homens representam e representam-se no mundo que os cerca" (FALCON, 2006, p. 338). A história da educação recebeu aportes da história cultural trazendo novos temas e problemas:

é, sobretudo no campo da história das instituições escolares que o impacto da história cultural da sociedade é mais complexo. Não somente porque a escola se torna um objeto de grande interesse para ela, mas principalmente porque a massa de estudos produzida sobre questões de produção, circulação e apropriação culturais abre novas perspectivas e põe novos problemas à investigação. Isso implica, por um lado, que os resultados destes estudos sejam conhecidos e, quando for o caso, incorporados, e por outro, que procedimentos de análise sejam refinados de maneira a que se dê conta do modo pelo qual as práticas escolares funcionam enquanto dispositivos de transformação material de outras práticas culturais e de seus produtos". (NUNES; CARVALHO, 1993, p. 49-50).

Nesse sentido, a construção de um banco de testemunhos orais naquele momento, no âmbito do MAHLS, também levava em consideração os estudos sobre práticas culturais, notadamente sobre cultura escolar que, conforme Julia, delimita, tanto de forma tangível quanto intangível, "conjunto de normas que definem conhecimentos a ensinar e condutas a inculcar, e um conjunto de práticas que permitem a transmissão desses conhecimentos e a incorporação desses comportamentos" (2001, p. 10). O acervo ${ }^{3}$ museológico já existente reunia coleções de objetos como lousa, uniformes, instrumentos e livros didáticos, fotografias, documentos, livros memoriais, pertencentes à cultura escolar lassalista de épocas específicas, uma vez que a rede de escolas se faz presente no Rio Grande do Sul desde $1907 .^{4}$

Para sua comunicação, promovem-se estudos instrumentais dos objetos (identificação, classificação, organização, levantamento de dados históricos) e pesquisa propriamente dita (investigações e estudos que levam a novas abordagens, conceitos e interpretações), cujos resultados são devolvidos à comunidade por meio de exposições, ações educativas e ou culturais, publicações, entre outros. Nesse contexto, os testemunhos orais colaboram para o tratamento técnico das coleções, para a política de conservação e sua reinserção no universo lassalista e inserção na comunidade do seu entorno, deslocando “[...] o centro das preocupações do objeto para o sujeito social [...]”. (JULIÃO, s/d, p. 95), sem minimizar a importância do acervo, mas tendo-o como foco de produção de

\footnotetext{
${ }^{3}$ Para saber mais, ver Graebin e Almeida (2015).

${ }^{4}$ Os Irmãos e alguns funcionários, mesmo que não de forma institucionalizada, haviam tido cuidado com os acervos, dedicando-se a salvaguardá-los. Foi a partir desse colecionismo que se originou o acervo do Museu Histórico.
} 
conhecimento. Trata-se aqui o depoimento oral como fonte da historiografia, que juntamente com outras, tornam possível abordar o cotidiano de escolas, condições de trabalho e de formação de professores, formas de sociabilidade, comemorações e celebrações, rituais, enfim, aspectos materiais e simbólicos da cultura escolar.

É relevante ressaltar que o trabalho com fontes orais já se fazia presente no Unilasalle desde 1994, quando uma parceria firmada entre a instituição e a Prefeitura Municipal de Canoas, iniciou o Projeto "Canoas - Para lembrar quem somos" que, por meio da metodologia da História Oral, buscava construir a história dos bairros da cidade. Essa iniciativa se inseria na compreensão, entre os historiadores, desde o movimento da Nova História ${ }^{5}$, do alargamento das fontes, entendidas como qualquer traço/vestígio que exprimisse e atestasse a presença do ser humano. Ao texto escrito, jantaram-se, por exemplo, os artefatos e depoimentos orais.

Também, entendeu-se que os depoimentos orais levantados a partir do Projeto se enquadravam na categoria de bens culturais imateriais, como saberes sobre práticas, modos de ser e de viver, celebrações e comemorações, formas de expressão em ambientes escolares, assim como o lugar escolar abrigando práticas culturais coletivas. A Constituição Federal havia ampliado a noção de patrimônio cultural ao reconhecer, a partir dos artigos 215 e 216, a existência de bens de natureza material e imaterial ${ }^{6}$. Neste sentido, podem-se enquadrar as memórias escolares, as quais são produzidas, como neste caso, a partir da metodologia da História Oral.

No Brasil, o caminho de construção e consolidação da História Oral deu-se: (1) a partir de 1974 com a criação de disciplina denominada Técnicas da História Oral, no Programa de Pós-Graduação em História e da fundação do Laboratório de História Oral em 1975, da Universidade Federal de Santa Catarina (UFSC); (2) pela instituição do Programa de História Oral da Fundação Getúlio Vargas (FGV) em 1975, ligado ao Centro de Pesquisa e Documentação o de História Contemporânea do Brasil (CPDOC), o qual conta atualmente (2016) com mais de 1000 entrevistas com personalidades brasileiras. $^{7}$ Ferreira informa:

\footnotetext{
5 “[...] a partir da década de 1980, registraram-se transformações importantes nos diferentes campos da pesquisa histórica. Revalorizou-se a análise qualitativa e resgatou-se a importância das experiências individuais, ou seja, deslocou-se o interesse das estruturas para as redes, dos sistemas de posições para as situações vividas, das normas coletivas para as situações singulares. Paralelamente, ganhou novo impulso a história cultural, ocorreu um renascimento do estudo do político e incorporou-se à história o estudo do contemporâneo." (FERREEIRA, 2002, p. 319).

6 “O patrimônio imaterial é transmitido de geração a geração, constantemente recriado pelas comunidades e grupos em função de seu ambiente, de sua interação com a natureza e de sua história, gerando um sentimento de identidade e continuidade, contribuindo para promover o respeito à diversidade cultural e à criatividade humana." PATRIMÔNIO Imaterial. Disponível em http://portal.iphan.gov.br/pagina/detalhes/ 234 Acesso em setembro/2015. Ver ainda: Convenção da Unesco para a Salvaguarda do Patrimônio Cultural Imaterial, ratificada pelo Brasil em março de 2006. Decreto $n^{\circ}$. 3.551, de 4 de agosto de 2000 - que instituiu o Registro de Bens Culturais de Natureza Imaterial e criou o Programa Nacional do Patrimônio Imaterial (PNPI) - e consolidou o Inventário Nacional de Referências Culturais (INCR).

${ }^{7}$ Para saber mais acessar http://cpdoc.fgv.br/
} 
A novidade dos programas de História Oral do CPDOC e do Departamento de História da Universidade Federal de Santa Catarina foi exatamente propor a constituição de acervos de depoimentos orais de História de vida, de representantes da elite política brasileira. Ainda que esse novo campo de trabalho despertasse, na época, pouco interesse e, em alguns casos, fortes resistências, a possibilidade de sua afirmação pode ser explicada a partir da abertura de novos centros de pesquisa e programas de pósgraduação nas universidades brasileiras. (1994, p. 9).

O conteúdo dos acervos orais produzidos nos anos 1970 e início dos 1980 tornou-se importante para as pesquisas desenvolvidas sobre o período da ditadura militar em que pesem as possíveis (e pouco estudadas) intervenções quanto aos registros memoriais guardados pelas instituições. Outra contribuição foi a publicação da obra de Carlos Corrêa, História Oral: Teoria e Técnica, resultante de dissertação defendida pelo autor no programa de Pós-Graduação em História da UFSC em 1977 (publicada em 1978), que se tornou o primeiro manual brasileiro em História Oral (NETTO, 2013; SANTHIAGO, 2015; SCHUTZ, 2014). No decorrer dos anos 1990 os trabalhos com História Oral ganharam destaque. Antes disso, Ferreira informa que "a história oral não merecia figurar nos currículos dos cursos universitários, implicava pouca reflexão e não constava na programação de seminários e simpósios" (1998, p. 20).

Ao iniciar os anos 1990, teve-se o crescimento das pesquisas no país com a utilização da metodologia da história oral, incentivadas pelas novas correntes historiográficas como a História Cultural, a História do Cotidiano e a História das Mentalidades, as transformações da sociedade brasileira, o aumento da criação e consolidação de programas de pós-graduação, os estudos sobre memória, a criação da Associação Brasileira de História Oral em 1994, congregando oralistas brasileiros, a fundação da Associação Internacional de História Oral, possibilitando o contato e socialização de saberes entre os pares. Também é importante lembrar as diferentes correntes sobre o trabalho com História Oral: (1) documento oral para suprir lacunas não preenchidas pela documentação escrita; (2) valorização da relação entre memória e história e estudo das representações; (3) questionamentos sobre a crítica história às fontes orais, lembrando-se da relação entre entrevistador/entrevistado o que poderia prejudicar a análise das mesmas; (4) condição de generalização de um testemunho ou considerar sua singularidade, apartado do todo social, espaço de vivência do entrevistado (NETO; MACHADO; MONTENEGRO, 2009). O trabalho com história oral, não se resume a utilizar determinada metodologia, mas está relacionado a uma filiação teórica, a escolhas temáticas e compreensão sobre os sujeitos da pesquisa.

O formato do banco de depoimentos orais foi inspirado no trabalho do Museu da Pessoa, criado em São Paulo em 1991 e definido como museu virtual, para registrar, preservar e comunicar histórias de vida de qualquer pessoa da sociedade. Ao longo dos seus 25 anos, a instituição tem refletido sobre sua prática e sobre a adaptação das atividades com História Oral, tendo em vista o desenvolvimento e possibilidades do uso da Internet, bem como ampliou sua 
área de atuação para outros países, chegando a formar redes internacionais e regionais de ação em torno de projetos de memória. Este trabalho tem grande difusão em diferentes grupos sociais, o que redundou na sistematização de metodologias, conceitos e ferramentas no que o Museu chamou de Tecnologia Social da Memória. ${ }^{8}$

Em se tratando de bases teóricas, o Projeto Memória Lassalista insere-se no campo de estudo da memória social (de difícil conceituação), que atravessa diferentes outros campos do saber e que pode ser abordado a partir de diversas linhas teóricas. Gondar informa que:

Há sempre uma concepção de memória social implicada na escolha do que conservar e do que interrogar. Há nessa escolha uma aposta, um penhor, uma intencionalidade quanto ao porvir. Tanto quanto o ato de recordar, nossa perspectiva conceitual põe em jogo um futuro: ele desenha um mundo possível, a vida que se quer viver e aquilo que se quer lembrar. $\mathrm{O}$ conceito de memória, produzido no presente, é uma maneira de pensar o passado em função do futuro que se almeja. Seja qual for a escolha teórica em que nos situemos, estaremos comprometidos ética e politicamente. (2005, p. 17).

Haverá sempre uma decisão com dimensões políticas e éticas ao trabalhar-se com memória social e com depoimentos orais, principalmente em se tratando de construção de história institucional, pois como informa Magalhães, “[...] a instituição é contexto, representação, materialidade e é apropriação" (2004, p. 67). O passado não está pronto, nem as memórias sobre ele. O acontecido só se torna conhecido a partir de um corpus documental e da voz de quem recorda cuja narrativa perpassada por afetos, silêncios e hesitações abre uma janela para compreenderem-se representações, significados, deslocamentos, enraizamentos e desenraizamentos de quem teve sua vida ligada direta ou indiretamente a trajetória de uma escola. Bosi (2003) indica que esta demanda do homem contemporâneo aponta para a formação de identidade e a necessidade de enraizamento, ou seja, "o vínculo com o passado, que é vital, porque dele se extrai a seiva para a formação da identidade”. (BOSI, apud BRUCK, 2012, p. 198).

Ao iniciar-se o Projeto Memória Lassalista, buscou-se fundamentação em Maurice Halbwachs (1990), para o qual lembrar é repensar, reconstruir vivências e experiências do passado, a partir do que está disponível no presente. É o indivíduo que recorda, mas está ancorado em grupos sociais que lhe servem de referência (família, escola, igreja, etc.). Cada grupo tem um modo que lhe é inerente de lembrar, da memória ser construída, compreendida e compartilhada de forma coletiva. Isto remete à cultura escolar (códigos compartilhados), como uma espécie de quadro social a partir do qual se ancoram as lembranças.

8 Disponível em http://www.museudapessoa.net/public/editor/livro_tecnologia_social_da_memoria.pdf Acesso em dezembro de 2015. 
Outro autor cujos pressupostos auxiliam nos questionamentos sobre memória é Michel Pollak, para quem "a memória é um elemento constituinte do sentimento de identidade, tanto individual, como coletiva" (1992, p. 204). Compreendendo a memória como construção e como objeto que se organiza a cada interpelação, esta é constantemente ressignificada e enquadrada a fim de atender as demandas do grupo. Pensando a escola como uma organização, esta “[...] veicula seu próprio passado e a imagem que ela forjou para si mesma. [...] O que está em jogo na memória é também o sentido da identidade individual e do grupo". (POLLAK, 1989, p. 8).

No processo de elaboração e implantação do Projeto, refletiu-se sobre: a construção de memórias, sua instância individual e coletiva; a relação entre o espaço, memória e cultura escolar; a relação memória e esquecimento e as disputas pela memória. No decorrer das entrevistas, percebeu-se que aparecia em algumas falas a necessidade de conhecer as escolas lassalistas da forma mais exata possível a partir das coleções do MAHLS ou pelos testemunhos orais. Isto fez com que se buscasse em Benjamin (1994) e Ricouer (1997, 2007), elementos para dar conta do ofício proposto, ou seja, organizar a memória das escolas e da educação lassalista. Assim, de Benjamin, captou-se que a tarefa não é a de reconstituir/conhecer o passado como ele de fato foi, mas sim articular passado e presente, aproximando-os, comparando-os, com uma função pragmática, isto é, utilizar o passado, em nome da sobrevivência. Aguarda-se a reminiscência, sem ter um ponto de partida, pois é a "[...] imagem do passado que se oferece inesperadamente ao sujeito histórico num momento de perigo [o presente]". (BENJAMIN, 1994, p. 224).

Em Ricoeur $(1997 ; 2007 ; 2012)$ aprendeu-se a pensar que os documentos, seja qual for seu estatuto, são requisitos para a narrativa histórica. O rastro se coloca como presença de uma ausência, um vestígio, marca da anterioridade que permanece no tempo, um indício sugerindo uma passagem. O passado só poderia ser atingido, no momento presente, a partir dos rastros, sem a intenção do passado como ele foi, mas uma forma de recuperação, aberta a interpretações e reflexões, tanto por parte de quem escreve como quem lê. As coleções de documentos (escritos, orais) e objetos "são rastros e os arquivos [museus] reservas de rastros inventariados [...]" (RICOEUR, 2012, p. 334). O autor pensa o arquivo como lugar físico (abriga os rastros) e lugar social (condição histórica daquilo que abriga). No momento que ocorre a operação historiográfica a partir dos rastros, pela narrativa do historiador, a memória se torna história. Ricoeur discute a questão dos arquivos para mostrar a interconexão entre memória e história e trata da transformação do testemunho oral em documento custodiado.

Naturalmente, se os escritos constituem a porção principal dos depósitos de arquivos, e se entre os escritos os testemunhos das pessoas do passado constituem o primeiro núcleo, todos os tipos de rastros possuem vocação de serem arquivados. Nesse sentido, a noção de arquivo restitui ao gesto de escrever toda a amplitude que lhe confere o mito do Fedro. Pela mesma razão, toda a defesa do arquivo permanecerá em suspenso, na medida em que não 
sabemos, e talvez não saibamos jamais, se a passagem do testemunho oral ao testemunho escrito, ao documento de arquivo, é, quanto a sua utilidade ou seus inconvenientes para a memória viva, remédio ou veneno - pharmakon... (RICOEUR, 2007, p.178).

Tem-se, a partir de Ricoeur, elementos para discutir a relação entre memória e documento, memória e história, memória e esquecimento. No caso do MAHLS, pensa-se o museu como espaço onde se preserva informações da memória e precisa-se levar em consideração o que foi descartado, a ameaça inquietante da relação entre história e memória, isto é, o esquecimento.

Não é somente o caráter penoso do esforço de memória que dá à relação sua coloração inquieta, mas o temor de ter esquecido, de esquecer de novo, de esquecer amanhã de cumprir esta ou aquela tarefa; porque amanhã será preciso não esquecer... de se lembrar. Aquilo que [...] chamaremos de dever de memória consiste essencialmente em dever de não esquecer. (RICOUER, 2007, p. 48).

Os arquivos e museus escolares são locais que acondicionam os rastros e que lhes garantem confiabilidade; são os lugares onde se celebra fragmentos do passado das escolas, "salvos" do esquecimento. O Projeto Memória Lassalista coloca-se como uma ação de um dever de memória, ou, como coloca Ricoeur, como já citado anteriormente, dever de não esquecer.

Essas reflexões levaram os proponentes e continuadores do projeto memória Lassalista a se questionarem sobre o seguinte: Ao entender os depoimentos orais como rastros e promovendo o seu armazenamento no MAHLS, não se estaria caindo em uma cilada, dando às memórias dos entrevistados certa materialidade, ou seja, uma ideia estática de memória social? Para resolver o impasse, trazem-se aportes de Dodebei (2005) no sentido de que os traços deixados pelo homem, neste caso os depoimentos orais, são potenciais de memória e que "somente a circunstância da atualização desses traços e vestígios é que lhes poderá conferir o caráter de documento" (2005, p. 44). Os depoimentos orais por si só, não são suficientes para a construção da história da educação e das escolas lassalistas, mas sim, a sua relação com os movimentos circunstanciais para a criação de memórias. Estes, por sua vez, estão relacionados a relações entre "[...] memória e cultura, memória e patrimônio e memória e coleção" (idem, p. 44). Assim, pode-se pensar que o Projeto Memória Lassalista produz a partir dos depoimentos orais, fragmentos de memória depositados no museu, sendo sempre “[...] potenciais na construção de memórias sociais". (DODEBEI, 2005, p. 44).

\section{O Projeto Memória Lassalista: constituição e operacionalização}

No decurso da trajetória do Projeto, após elaborar e tê-lo aprovado pelas diferentes instâncias institucionais, passou-se à compra de equipamentos, ou seja, 3 gravadores que utilizavam fitas cassete e a montagem inicial de uma comunidade de destino. Esta, de 
acordo com Bosi (1994), compreende os colaboradores da pesquisa e sua constituição tem de levar em consideração as vivências e experiências coletivas (elementos físicos e subjetivos) que os aproximam. Dessa maneira, pensou-se em uma comunidade de destino formada por irmãos, ex-irmãos, professores, alunos e ex-alunos de comunidades educativas lassalistas da Região Metropolitana de Porto Alegre. Apesar de o Projeto prever como universo de pesquisa as escolas lassalistas do Rio Grande do Sul, iniciou-se com um piloto, abrangendo aquelas mais próximas do Unilasalle Canoas.

A partir daí, fez-se uma seleção em termos de quais Irmãos, professores, alunos, etc. seriam os colaboradores da pesquisa. Alguns dos critérios para a escolha: o geracional, isto é, trabalhar-se com diferentes gerações; posição no grupo, significado das experiências, papel na instituição; entre outros. Para tanto, recorreu-se a pessoas consideradas como estratégicas, recolhendo informações por meio de entrevistas mais curtas, exploratórias, que forneceram elementos fundamentais para a continuidade da formação da comunidade de destino. Documentação importante para esta etapa foi a publicação denominada Vidas Lassalistas com volumes dedicados a biografias dos Irmãos. Uma entidade a quem se recorreu, foi a Associação de Ex-Alunos do Colégio La Salle Canoas, para a indicação de potenciais colaboradores.

$\mathrm{Na}$ sequência, constituiu-se a equipe de pesquisa que foi formada por alunos e professores do curso de História do Unilasalle. Os alunos receberam bolsas de iniciação científica da instituição, bem como orientação a partir de formação intitulada "Oficinas de Lembranças", com 40 horas de duração, durante as quais receberam informações sobre a metodologia da História Oral, discutiram textos teóricos e realizaram testes com as técnicas de entrevista e transcrição dos depoimentos. A grande preocupação era e continua sendo, a de que os pesquisadores tenham uma posição dialógica junto ao entrevistado e que estejam integrados com os demais participantes da equipe e com o Projeto em si. Ressaltase como indica Pollak (1989), que é preciso ter empatia com os sujeitos, pois o ato de narrar é envolto por disputas e jogos estratégicos.

Para a coleta de depoimentos de alunos e professores, escolheu-se a entrevista temática semidirigida, conduzida com o propósito de perceber a relação entre o indivíduo e a história institucional. Lembrando Alberti, a partir de um conjunto de depoimentos:

[...] trata-se de ampliar o conhecimento sobre acontecimentos e conjunturas do passado através do estudo aprofundado de experiências e versões particulares; de procurar compreender a sociedade através do indivíduo que nela vive; de estabelecer relações entre o geral e o particular através da análise comparativa de diversos testemunhos, e de to mar as formas como o passado é apreendido e interpretado por indivíduos e grupos como dado objetivo para compreender suas ações. (2004, p. 19).

As entrevistas com os Irmãos são do tipo história de vida, uma vez que estes chegam à instituição lassalista ainda muito jovens e sua trajetória relaciona-se diretamente, em todas as etapas sequentes, à trajetória da instituição. De qualquer maneira, cada entrevista, temática ou história de vida, traz uma breve biografia, pois como indica Alberti (2004), o 
acervo, ao ser aberto à comunidade de pesquisadores externos, precisa fornecer dados sobre o entrevistado. Nesse sentido, o entrevistador inicia a conversa com perguntas sobre a infância e a socialização do entrevistado: onde e quando nasceu, origens familiares, primeiros estudos etc. Em seguida, procura acompanhar seu rumo até a entrada em uma instituição lassalista, tanto para o caso de professores e alunos, quanto também, para aqueles que abraçam a vida religiosa na congregação. A autorização para a utilização do documento oral é realizada após a transcrição e conferência da entrevista pelo colaborador.

A gravação dos depoimentos iniciou com gravadores de fita cassete e, em 2006, passou-se a utilizar gravadores digitais. Após a gravação, os depoimentos recebem o seguinte tratamento: cuida-se da integridade dos depoimentos — a sua identificação e localização, a conservação e a guarda patrimonial; na sequência elaboram-se dados e informações (sumário e índice temático) sobre os depoimentos para possíveis buscas por parte de pesquisadores/outros. Após, faz-se o trabalho de transcrição e conferência, quando se dá o formato final ao texto. Para tanto, adotou-se a metodologia descrita e aplicada no trabalho desenvolvido por Szymanski, Almeida e Prandini (2002). ${ }^{9}$

É relevante apontar para a complexidade que envolve a criação de arquivos sonoros, uma vez que a velocidade da evolução das tecnologias dificulta a sua consulta, conservação e arquivamento. As fitas cassetes, por exemplo, dependem de equipamentos que as reproduzam, bem como são de difícil manutenção, o que leva à sua reprodução em outros suportes. Mesmo assim, não se tem a garantia da longevidade destes outros suportes, fazendo com que se procure estar em consonância com as novas formas de armazenamento que são postas à disposição na Web, o que depreende constante atualização por parte daqueles que são responsáveis pelos arquivos orais. ${ }^{10}$

O ponto vulnerável do Projeto é a disponibilização dos depoimentos orais online para o público interessado. Isto depende, não só de espaço na página do Unilasalle, como também de recursos humanos especializados para atualização dos dados. Desta maneira, até 2016, conseguiu-se montar e manter atualização do banco de dados do Projeto Memória Lassalista, disponibilizando os conteúdos a partir de agendamento e consultas prévias. No entanto, conseguiu-se avançar e terá início a partir de março de 2017, a disponibilização das entrevistas no Portal do MAHLS, em texto escrito e áudio. Prepara-se, também, outra etapa do Projeto que constará de gravações dos depoimentos em audiovisual.

Concomitante ao processo de coleta de depoimentos discutiu-se como proceder à sua organização. Em primeiro lugar, definiu-se que os documentos gerados pelo Projeto se caracterizam como originados por meio de pesquisa para servir de apoio a futuras investigações, notadamente sobre instituições escolares e história da educação, fazendo parte de uma das atividades meio e fim do MAHLS. Segundo (CHANGEUX, apud LE GOFF):

\footnotetext{
${ }^{9}$ Para saber mais sobre análise de entrevistas ver: GOODSON, Ivor F. Dar voz ao professor: as histórias de vida do professor e o seu desenvolvimento profissional. In: NÓVOA, A (Org.). Vidas de Professores. Porto: Porto Editora, 1992. OLIVEIRA, Valeska Fortes. Educação, memória e histórias de vida: usos da história oral. História Oral , Recife, v. 8, n. 1, p. 92-106. jan./jun. 2005. SANTOS, Sônia Maria dos; ARAÚJO, Osmar Ribeiro de. História oral: vozes, narrativas e textos. Cadernos de História da Educação, n. 6, jan./dez. 2007. Disponível em: http://www.seer.ufu.br/index.php/che/article/view/282. Acessado em $12 / 06 / 2011$

${ }^{10}$ Para saber mais ver Alberti (2004).
} 
O processo da memória no homem faz intervir não só na ordenação de vestígios, mas também na releitura desses vestígios. Os lugares da memória coletiva se dão por meio das instituições depositárias da memória através dos seus documentos, tais como, as Bibliotecas, os Arquivos, os Museus, os Centros de Documentação e Referência, que armazenam, tratam e disponibilizam informações organizadas dessa memória, promovendo paulatinamente a construção do conhecimento. (2003, p. 473).

Neste sentido, cabe aqui uma problematização, ou seja, a utilização dos depoimentos realizados pela equipe do Projeto Memória Lassalista por pesquisadores de diferentes áreas do conhecimento. $\mathrm{O}$ acervo não foi criado apenas como um repositório de lembranças de Irmãos, alunos, professores, funcionários, enfim, envolvidos com a educação, a escola e instituições de ensino superiores lassalistas. O objetivo é o de que os testemunhos orais se constituam como fontes de outros estudos que tragam distintas leituras e interpretações, pois como aponta Portelli (1997), dirão mais sobre as subjetividades, os significados atribuídos a experiências e vivências, a saberes e fazeres dos depoentes do que propriamente sobre eventos a respeito da educação e escolas lassalistas. Isto não implica em invalidar o acontecimento, pois "entrevistas sempre revelam eventos desconhecidos ou aspectos desconhecidos de eventos conhecidos [...] contam-nos não apenas o que o povo fez, mas o que queria fazer, o que acreditava estar fazendo e o que agora pensa que fez" (PORTELLI, 1997, p. 31).

Para atender aqueles que buscam o acervo, a sua organização passou pelos seguintes procedimentos: com base em Bellotto (1991) e auxílio de profissionais da área da informação, neste caso, arquivista e museólogo, procedeu-se à criação do Fundo Memória Lassalista, subdividido em Grupos (unidades educativas-instituições de Educação Básica; centros de assistência social; instituições de ensino superior, casas de formação religiosa). Cada Grupo foi subdividido em Séries e Subséries, acolhendo as entrevistas em suporte fita cassete, digital e papel (transcrição). $\mathrm{Na}$ figura 01 a seguir, traz-se uma mostra da organização do Fundo.

Figura 1: Mostra de parte do Quadro de Arranjo dos depoimentos orais do Fundo Memória Lassalista

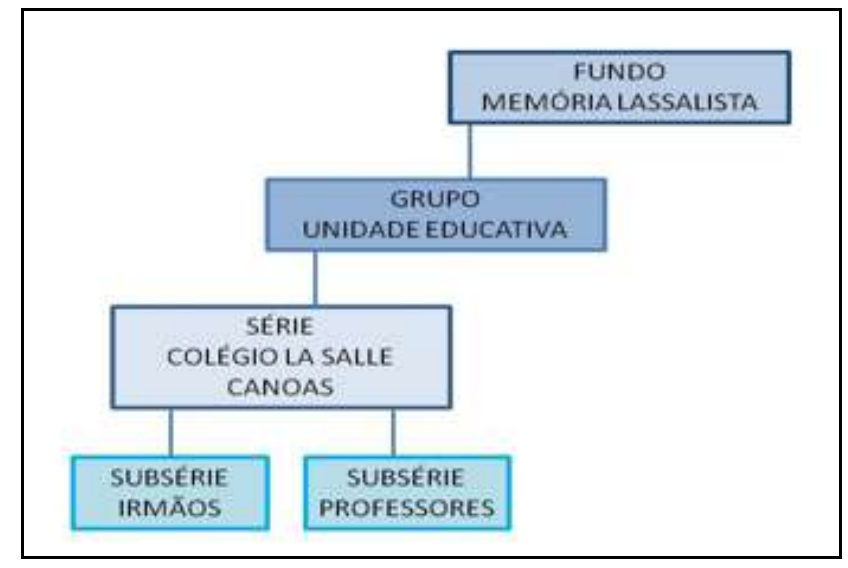

Fonte: Autoria própria (2014). 
O Fundo não está fechado, uma vez que este tipo de trabalho tem uma natureza inconclusa. Portelli afirma ser "[...] impossível exaurir a memória completa de um único informante, dados extraídos de cada entrevista são sempre o resultado de uma seleção produzida pelo relacionamento mútuo [entrevistado/entrevistador]" (1997, p. 36). Assim, o Fundo é aberto e enquanto houver equipes dispostas a dar continuidade ao Projeto, mais testemunhos poderão ser acrescentados, inclusive continuar a entrevistar, periodicamente, depoentes que já colaboraram com suas falas.

\section{Possibilidades de utilização de depoimentos orais}

Os depoimentos orais têm potencialidade para além do banco de dados. Eles auxiliam a abrir a chamada "caixa preta" de uma instituição escolar, ou seja, a cultura escolar, as práticas pedagógicas, o currículo e as disciplinas, para a compreensão do que acontece no seu intramuros (JULIA, 2001). As memórias dos atores sociais no interior das unidades educativas lassalistas auxiliam na compreensão do entrelaçamento entre suas experiências e a própria história dos Irmãos Lassalistas e de suas escolas. O MAHLS não é só depositário do acervo, mas se constitui como construtor de identidade institucional. Para além das escolas e educação lassalista, os depoimentos orais apontam e elucidam elementos que integram a construção de políticas educacionais, de projetos políticospedagógicos, formulação de currículos, entre outros.

Também, fornecem pistas para a problematização da instituição escolar em se tratando de formas de controle, reprodução do poder e de produção de obstáculos que influenciam em processos de mudança. Werle informa que:

As instituições são lugares de ação social e, como tal, marcadas pelo tempo, espaços e pessoas; são formas sociais dotadas de organização jurídica e material, cujo estudo envolve a análise de suas origens, gênese, estabilidade, rupturas e processos de formação. Elas são o espaço real, tanto objetivo como subjetivo, no qual vivenciamos relações, valores, normas, poder, experiências de lideranças, rivalidades, conflitos e competição. (2004, p. 111).

Uma instituição, e neste caso, a escolar, tem sua razão de ser nos alunos, professores, funcionários, equipe diretiva que lhe dá vida. Sem estes, sobra apenas a edificação. Costa (1997) chama a atenção para duas forças no interior das instituições: a memória-arquivo (informações e regras para manutenção da ordem) e a memória-hábito (comportamentos e condutas) que tanto podem mantê-la, como corroê-la por dentro. O seu crescimento pode se dar no interstício entre as duas, onde há espaço para a mudança, a qual surge, em grande parte, pela chegada de novos membros. Quando os atores constroem memórias de suas trajetórias, é possível desvelar relações interpessoais, institucionais e grupais ressignificadas que auxiliam na reflexão sobre a dinâmica de uma instituição de ensino. É importante considerar que grande parte dos entrevistados têm vínculos com a instituição e 
decidem o que lembrar e o que silenciar/ocultar/recortar/montar. Por vezes, a narrativa é laudatória, o que não a invalida, mas obriga o pesquisador a estar atento a algumas variáveis como envolvimento profissional e afetivo, o que faz "[...] a complexidade do trabalho com memórias, sua relatividade, tanto quanto sua capacidade de constituir-se como documentação histórica". (GRAZZIOTIN; ALMEIDA, 2012, p. 14).

O depoimento oral nunca é neutro, haja vista que é gerado em interação com o pesquisador. Então, neste face a face, já se apresenta o rompimento de um suposto equilíbrio preexistente, trazendo um possível desconforto em relação à preservação de autoimagem. Goffman pode auxiliar no trabalho com depoimentos orais, a partir do conceito de face, ou seja, "o valor social positivo que uma pessoa efetivamente reclama para si mesma através daquilo que os outros presumem ser a linha por ela tomada durante um contato específico." (1985, p. 77). A partir deste autor, Brown e Levinson (1987), trazem que há uma dualidade, isto é, face positiva (necessidade de aceitação) e face negativa (desejo de autoafirmação). Já Tracy e Baratz (1994) criticam as autoras anteriores colocando que a preocupação com a face deve ser contextualizada histórica e socialmente, levando em conta a história dos atores e as situações individuais, incluindo aí a emocional, no momento do ato de fala.

Neste sentido, quando se entrevista um professor, Irmão, aluno, para o projeto Memória Lassalista, estes são informados dos objetivos da pesquisa, mas, mesmo assim, não têm total controle do que será feito com seu relato. Assim, poderão adotar estratégias para resguardarem-se, apagando marcas da enunciação, adotando a impessoalidade (parece que, é provável que), a indeterminação do sujeito (diz-se, falava-se) e emprego de marcadores de rejeição (salvo engano, que eu saiba), dizendo, mas não assumindo o que foi dito.

Os depoimentos orais tornam-se potenciais para o estudo dos elementos da cultura organizacional escolar, que aparecem na sua zona de invisibilidade (valores, crenças, ideologias) e na sua zona de visibilidade (manifestações verbais, manifestações visuais e simbólicas, manifestações comportamentais) (NOVOA, 1992). O conhecimento e análise da cultura escolar auxiliam a compreender, por exemplo, semelhanças e diferenças entre escolas lassalistas, potencialidades e fragilidades, inovações, enfim o modo de ser particular de cada escola. Sarmento (2000) informa que cada escola tem seu próprio tempo histórico e ao se pensar nas escolas da Rede La Salle, embora pareça que há uma homogeneidade, advindas das orientações do Instituto dos Irmãos das Escolas Cristãs, aquelas têm suas próprias marcas, inscritas pelo seu percurso no tempo. $\mathrm{O}$ autor propõe a metáfora do palimpsesto para a instituição escolar, informando que para desvendá-la é preciso ater-se aos vários momentos de construção e reconstrução de sua história e das múltiplas continuidades e descontinuidades, promovendo leituras que se cruzam e se sobrepõem, configurando a cultura organizacional. Uma rápida leitura do conjunto das entrevistas do Projeto, já possibilita diversificada e não necessariamente convergentes visões institucionais.

\section{Algumas problematizações a partir do acervo do Projeto Memória Lassalista}

Para que se tenha ideia do conteúdo dos depoimentos, reproduzem-se alguns trechos de entrevistas com um Irmão Lassalista, Germano Rebellatto (entrevistado em maio/2004), e três ex-alunos do Orfanato Pão dos Pobres de Santo Antônio, existente em Porto Alegre, 
RS, desde 1895, passando a ser dirigido pelos Irmãos Lassalistas a partir de 1926 (atualmente chama-se Colégio La Salle Pão dos Pobres). Essas entrevistas foram realizadas em setembro de 2006. ${ }^{11} \mathrm{Na}$ sequência, guardadas as proporções deste artigo, discutem-se algumas questões sobre a relação entre memória e oralidade, a partir da leitura dos depoimentos.

Irmão Germano Rebelatto Quando ela foi registrada [Escola Profissional La Salle junto à Gráfica La Salle] como escola, antes disso já havia alunos aprendendo, mas nós queríamos dar diploma e não tínhamos registrado na Secretaria da Educação [do RS], então tinha que fazer um trabalho especial. Era interessante, porque aqui no externato São Luiz [atual Colégio La Salle Canoas] terminavam o ginásio né? Então tinha um aluno muito conhecido, muito estimado, muito inteligente. E o pai veio lá com o menino, o guri se chamava Walter Galvani ${ }^{12}$ (risada), conheces? Então ele disse assim: eu tenho o meu garoto aqui, eu não posso dar para ele a faculdade agora porque é muito novo, tem seus 13 anos, dá pra ele aprender alguma coisa aqui dentro? Falou assim para o Irmão. Ficou quatro anos o Walter Galvani lá como aluno aprendendo a compor à mão, ele compunha, montava aquela chapa e tal. Outros funcionários diziam: como é que o guri tá ali? Eu tenho em casa também o meu guri que estuda de manhã e de tarde ele ia jogando bola, não aprende nada, dá para ele entrar aqui? Aí o Irmão disse pode vir. Tínhamos empregados porque o serviço aumentou ainda aqui perto do colégio, ali tinha um batalhão. Tínhamos doze guris, então o Irmão Amadeo Maria, disse: mas eu acho que nós vamos pedir para registrar como Escola, porque os guris estão aprendendo aqui. Então ele encaminhou aqui na Secretaria da Educação e Cultura de Porto Alegre um pedido, foi em 1953 que encaminhou, demorou, demorou. Em 1953 nós já estávamos lá no novo prédio, aí aumentou os alunos, aumentou os guris porque tinha espaço, tinha tudo em 1958, então já veio o atestado para os alunos terem um diploma. A Secretaria de Educação pediu pra que nós ensinássemos encadernação, composição, impressão, todo o setor gráfico, então se chamava Artes Gráficas. No começo, um aprendia uma coisa só, era meio limitado, foi o que aconteceu com os primeiros alunos. Eles se formavam, por exemplo, em montar tipos, conheciam né, mas aí depois que a Secretaria de Educação pediu pra nós ensinar todo o setor gráfico, então se fez isso né e continuou, tinha os que aprendiam o linotipo, aquela máquina complicadíssima. Então ficou assim, de 1958 em diante nós pudemos então dar o atestado, fazer uma formatura. Escola Profissional La Salle, eu vou agora dizer em que consistia, ela era tipografia, marcenaria, sapataria, alfaiataria e padaria. Cinco setores e tudo funcionava. Funcionavam no começo, depois começou a parar um, depois parou outro, parou outro e aí ficou só a Gráfica. Ficou a gráfica e a marcenaria. Na marcenaria não queriam colocar meninos porque as máquinas são muito perigosas, a plaina, a serra. Apesar disso formou um ou dois rapazes lá, mas sem diploma porque não queria chamar a atenção que tinha aluno na marcenaria, porque na marcenaria tem que ser só ferramenta manual para trabalhar. Na máquina motorizada, qualquer coisinha corta o dedo fora. Então não foi autorizado a ter alunos mais na marcenaria.

\footnotetext{
${ }^{11}$ Para este trabalho, os trechos das entrevistas foram editados.

${ }^{12}$ Destacado jornalista e escritor no Rio Grande do Sul.
} 
Meu nome é Edson Monin, ingressei no Pão dos Pobres em 1939, e saí em dezembro de 1947. O Pão dos Pobres pra mim foi muito bom, em primeiro lugar o ensinamento. Eu entrei e comecei a aprender quando eu tinha nove anos de idade. Fiz o primeiro, segundo, terceiro, quarto e até o quinto ano que naquela época já era bom, que equivalia à primeira série que era chamada a admissão. Aí, em 1944, fui para a turma dos maiores onde tirei o curso de mecânica. Passei por todas as especialidades desde o serralheiro até torneiro, ajustador todos os ofícios que foi interessante pra mim. E após a saída do Pão dos Pobres eu achei que precisava estudar um pouco mais que naquela época tinha o Irmão Edmundo que tinha uma grande visão sobre o estudo, e nos adiantou ai uns três, quatro anos de matemática e português que me valeu bastante e após a isso, aí antigamente as turmas se formavam em um ano saiam no ano seguinte após o carnaval, para a pessoa não ir ao carnaval. A minha turma foi a primeira turma que se formou dentro do ano porque nós saímos em vinte oito de dezembro de 1947. Dentro do ano neste de 1947 houve duas turmas, a que era de 46 que saiu no principio e a de 47 que nós saímos, bom, depois disso, achei que deveria estudar um pouco mais, ai me preparei para fazer um curso na Varig em 1951. Aí me pedia um curso de até a terceira série, ai eu não tinha mas não precisava apresentar documento. Fiz, passei e fui bem lá nos testes, ganhei um bom salário lá. E em vista de dificuldades, deixei de trabalhar na Varig e ingressei em uma companhia americana como aprendiz de mecânico, apesar de ser mecânico há muitos anos, na qual trabalhei trinta anos e me aposentei. O Pão dos Pobres é muito bom, certo? Porque dá o básico para o pessoal. Quem acha que é pouco deve continuar estudando um pouco mais para melhorar de vida como foi meu caso, que não tenho dificuldade nenhuma, vivo bem, como o que quero, me orgulho de ter frequentado o Pão dos Pobres.

Sou Eduardo Damacena, ingressei no Pão dos Pobres em 1943, em plena Segunda Guerra Mundial. A passagem que me lembro com muita frequência é a seguinte: quando entrei no portão ali aonde tem o portão ali, aonde tem o galpão ali, quem me recebeu foi Irmão Arsênio pelas mãos do Irmão Isidoro. Aí, eu todo faceiro, entrei um pouquinho também um pouco meio (receoso) ai ele me entregou para o Irmão Adalberto que era encarregado da rouparia. Aí, subi toda aquela escadaria do colégio e fomos até a rouparia. Aí, dizia ele "agora tu tira essa roupa e usa a roupa do colégio" que era uma calça curta e uma camisinha amarela. Aí me fardei com a roupa do colégio, mas o meu contentamento maior foi o seguinte: aí depois ele me deu o seguinte o fardamento de domingo, aí eu fiquei faceiro, quepe, cinturão, fardamento bonito e eu será que sou eu mesmo? Todo fardado parecia um tenente, e eu todo faceiro nunca tinha botado um fardamento em toda a minha vida, coloquei aquele quepe e não queria tirar mais. Barbaridade! E eu louco para que chegasse domingo para colocar o fardamento. Chegando o domingo, a gente colocava o fardamento pra ir pra missa, né, aí eu todo bonito de fardamento novo, parecia um oficial da Brigada ${ }^{13}$. Fiquei loco de faceiro ((ri)) e o Adalberto que cuidava da rouparia então. Ah! no quepe tinha o distintivo do Pão dos Pobres, hoje em dia eu tenho visto ele muito

13 Brigada Militar do Rio Grande do Sul (BMRS) ou brigada Militar (BM) - trata-se de força de segurança pública com os objetivos de policiamento ostensivo e preservação da ordem pública no âmbito do Estado do Rio Grande do Sul. Foi criada em 18/11/1937, com o nome de Força Policial. Sua denominação passou por várias modificações até chegar em 1889, como Brigada Militar ( FRANCO, 2006). 
frequente nos envelopes, aí, naquele emblema no Pão dos Pobres. Aquele a gente usava no quepe, era o orgulho pra gente usar aquele distintivo. Sobre o colégio, essa passagem eu nunca me esqueço.

Luis Antônio Fontani. Fui aluno desde [19]29, fins de 29, há quarenta e um anos, e quando entrei [no Pão dos Pobres] a primeira noite eu apanhei ((ri)) porque estava falando dormindo. Aí tive que correr no salão porque era um baita de um salão e é ainda, até hoje, um baita salão e o [Irmão] correndo atrás de mim até que acomodou tudo e tudo certo ai no dia seguinte. Tinha o Irmão Alberto, o Irmão Ernesto, naquela época. Tinha mais [Irmãos] que eu conheci para dar [continuidade no colégio] entendeu? Mas depois passou naquela época. Tinha o salão e ele tava vazio, tinha cama mas não tinha a gurizada total, entendeu? Aí com a quantidade foi penetrando, foi penetrando, aí foi que ocupou porque só se ocupava o andar de cima, o terceiro andar não era ocupado. Ainda tinha o pátio dos maior; era lado esquerdo, aliás o direito de frente e o outro lado era dos menor. Ai deu continuidade ((ri)).

O caso é o seguinte: eu comecei mas não expliquei direito donde eu vim. Vim do interior de Bento Gonçalves. Nasci em Porto Alegre, mas a minha mãe se mudou para Bento e depois arrumaram os [benfeitores] parece que era o Eduardo Secco, a família. Arrumaram porque a minha mãe era viúva e me colocaram no Colégio Pão dos Pobres. Aí eu entrei perto de 1929, entrei com sete anos e dei continuidade. Aí, naquela noite eu apanhei, e no dia seguinte recebi um Papai Noel de chocolate para me satisfazer, pra mim sorrir. Aí depois eu na andança dos anos, a gente ia tomar banho na Praia de Belas. O Irmão Casemiro naquela época era o prefeito [do orfanato], então trazia e voltava etc, ia pra aula, de manhã era aula, meio dia tinha um descanso, depois de tarde tinha aula de novo e eu fiquei até os quatorze anos estudando e teve como é que se diz, umas pixotadas, e nóis tinha... A gente pegava umas bolinha de inhoque (de balde) de noite que tinha de baixo da cama, e o Irmão prefeito via ficava doido ele queria pegar pra dar uma surrinha nessa gurizada, né, porque hoje a gente tá vendo que a gurizada anda meio sapeca, mas nós também era na época sapeca, né? Mas não com malvadeza e nem com violência, mas depois a gente foi andando, tinha os pequenino. Com de dois em dois meses ia pra Ipanema de trenzinho e tinha outra hora que era lá em Teresópolis no ônibus. Tinha alvo de tiro, tiro quatro e trezentos e dezoito ${ }^{14}$, e tinha mato então a gente fazia o churrasquinho e passava o dia, de noite, de tardezinha. Eu vou te dizer todo o armazém Todos Santos ali na entrada na Nonoai, entrava no armazém comprava meia garrafa de vinho comprava um pedaço de pão e um pedaço de linguiça e depois assava e passava o dia todo brincando e subia o morro e sabe como é que é criança, sobe, desce e ta tudo satisfeito e depois que me formei na carpintaria, trabalhei como marceneiro, carpinteiro uns quatro anos FIRME ${ }^{15}$. O Irmão Laércio foi muito bom, um professor meu e quando chegava as balsa de madeira ele tirava elas dentro do barco para enquadra ela e empilha e depois i, eu sai do colégio em [19]41 trabalhei um ano, dois ano, sentei praça, no fim fui pra guerra [2 ${ }^{\mathrm{a}}$ Guerra Mundial] sou um

\footnotetext{
${ }^{14}$ Treinamento militar.

${ }^{15} \mathrm{O}$ entrevistado dá uma grande ênfase na afirmação.
} 
ex-combatente, servi à pátria, fui conhecer o Papa [Pio XII], graças a Deus ainda beijei a mão dele e retornei são e salvo.

Uma das relações com memória, que emerge dos relatos orais, é a de que cada depoente elabora suas lembranças relacionando-as a contextos sociais, à construção de identidade e, por conseguinte, a grupos de pertencimento. Outro elemento é o de que a partir do trabalho de memória dos entrevistados, há uma narrativa do processo formativo e aprendizagens construídas (no caso dos ex-alunos) e a formação do outro (no caso do Irmão Lassalista). Nesse sentido, trata-se de identidade transformada por saberes, por influência de outros e por escolhas próprias em processo de construção de conhecimento.

As narrativas dos ex-alunos têm um tom épico, de saga e, segundo Bosi, "o narrador tira o que narra da própria experiência e a transforma em experiência dos que escutam" (1994, p. 85). É a partir das experiências narradas pelos ex-alunos que aqueles que escutam seu relato são incluídos no universo do Orfanato Pão dos Pobres de Santo Antônio, ou nas oficinas da Gráfica La Salle, por meio do depoimento do Ir. Germano Rebellatto.

Retomando reflexões de Portelli, a memória não é um depósito de fatos “[...] mas também um processo ativo de criação de significações" (1977, p. 33) e sua utilidade

[...] repousa não tanto em suas habilidades de preservar o passado quanto nas muitas mudanças forjadas pela memória. Estas modificações revelam o esforço dos narradores em buscar sentido no passado e dar forma às suas vidas, e colocar a entrevista e a narração em seu contexto histórico. (1977, p. 33).

Isto pode ser inferido a partir do depoimento de Luis Antônio Fontani que inicia sua narrativa por um fato ocorrido quando chegou ao Orfanato, mas logo retoma o depoimento, contextualizando-o:

O caso é o seguinte eu comecei mas não expliquei direito donde eu vim. Vim do interior de Bento Gonçalves. Nasci em Porto Alegre, mas a minha mãe se mudou para Bento e depois arrumaram os [benfeitores] parece que era o Eduardo Secco e família. Arrumaram porque a minha mãe era viúva e me colocaram no Colégio Pão dos Pobres.

Seu relato evidencia um esforço em organizar o passado, enunciando uma autobiografia, retomando momentos de sua vida. Trata-se de momento criativo que desvela a construção de identidade no instante mesmo da narrativa, a partir da linguagem. Percebese uma seleção de lembranças que promovem um encontro consigo mesmo, a partir daquilo que o afeta. Isto remete a refletir sobre o quanto dos depoentes está na construção da memória social do Colégio La Salle Pão dos Pobres e o quanto desse lugar social e das experiências de outros sujeitos se transfere para os mesmos, no momento do depoimento.

Portanto, embora as restrições e brevidade das discussões aqui iniciadas, julga-se relevante o acervo de depoimentos orais, tanto para a construção de memórias sobre a 
instituição lassalista e suas práticas e sobre educação e escolas, quanto para pensar teoricamente e metodologicamente esses temas. Nesse sentido, encaminha-se a seguir algumas considerações sobre a continuidade do Projeto.

\section{Perspectivas do Projeto Memória Lassalista}

Meneses informa que entre as funções de um museu tem-se aquela de ser espaço de estudo e pesquisa:

[...] também se vai ao museu em busca de informação, isto é, para levantamento de atributos empíricos de coisas, para apreensão imediata de dados — que ainda não constituem conhecimento - e também para a educação, para a formação, seja de natureza substantiva, seja metodológica. (2010, p. 14).

Refletindo sobre o MAHLS e seu status como museu universitário, trabalha-se, a partir de indicações de Meneses (2010), no sentido da produção de conhecimentos por meio de agenda de pesquisa institucional que alimente as exposições e as atividades educativas, culturais e de extensão, provocando mais questionamentos e, consequentemente, mais investigações de suas coleções. Isto abre para a história da educação e das instituições escolares, infinitas possibilidades de pesquisa a partir dos acervos museológicos. Busca-se a não cristalização dos depoimentos do Projeto Memória Lassalista pela sua constante renovação, inclusive refazendo, enquanto isto ainda for possível, de tempos em tempos, entrevistas já realizadas. Também, estudam-se procedimentos técnicos que atendam a este patrimônio vivo e dinâmico e o estreitamento dos laços entre o museu e as comunidades escolares, motivando que estas tenham papel ativo na sua salvaguarda; mediando a elaboração de projetos de memória e disponibilizando espaço, recursos, ações educativas e culturais. (CARVALHO, 2011).

O MAHLS, em 2016, inicia um trabalho de reordenamento, inserido no projeto de tornar o Centro Universitário La Salle em Universidade. Encaminhou-se aos Conselhos, um novo Regulamento e a renovação de seu Plano Museológico. Neste estão previstas ações, estratégias e operações em relação às suas múltiplas funções como museu universitário e às suas coleções, dinamizando-as a partir de políticas institucionais articuladas de forma solidária, fertilizando umas às outras, referenciadas por ações de natureza científico-documentais, educacionais e culturais. (MENEZES, 2010).

No bojo das mudanças, dedicou-se espaço privilegiado para o Projeto Memória Lassalista, pois nos 12 anos de sua existência, ocorreram muitos avanços em termos tecnológicos (recolhimento de depoimentos, formas de hospedagem) e divulgação, bem como em se tratando de procedimentos metodológicos e referenciais teóricos. No entanto, os desafios ainda são maiores ao se levar em consideração, por exemplo, a consolidação dos museus como espaços não formais de educação e cada vez mais, como espaços de lazer. No entanto, a maior parte da população do país ainda não tem acesso a estes equipamentos culturais, às pesquisas neles realizadas e às suas ações educativas e culturais. 
Se nestes anos iniciais premiaram-se os depoimentos de pessoas que estiveram diretamente relacionadas com as unidades de educação básica, urge dedicação a recolha de testemunhos sobre a educação superior que completa 40 anos no Rio Grande do Sul. Neste sentido, trata-se do alcance não só da comunidade acadêmica, a do entorno da instituição, mas também para fora do Estado, para audiências diversificadas. Outro desafio centra-se em ações de extensão universitária, interação com a formação de professores e com a educação básica.

Ainda é preciso refletir: sobre o conceito de patrimônio nas suas especificidades materiais e imaterias, não as dicotomizando, mas tratando-as em interação; as maneiras de hospedagem do acervo oral, notadamente na sua organização de forma digitalizada, circulando na memória virtual em um mundo interligado por redes de computadores. Dodebei ( $\mathrm{s} / \mathrm{d}$ ) traz importante discussão deste tema sobre o qual a equipe do MAHLS terá de se debruçar, uma vez que pretende inserir os depoimentos do Projeto Memória Lassalista em uma coleção virtual, já entendendo a constante necessidade de sua reformatação, de que aqueles não são o espelho da educação, das escolas lassalistas e da sua memória.

\section{Considerações Finais}

A produção de acervo oral constituído por testemunhos sobre a educação e as escolas lassalistas se coloca como relevante conjunto de fontes para o campo da história da educação, tendo em vista que trazem informações sobre alunos, professores, práticas pedagógicas, o cotidiano e a cultura escolar em diferentes momentos. Porém, não basta recolher os depoimentos, inventariá-los, preservá-los, organizá-los. É necessário constantemente atualizar, ressignificar e reinstalar as informações lá contidas a fim de que se possibilite o seu acesso. (MAGALHÃES, 1999).

Com o advento das noções de patrimônio imaterial e a multiplicação de estudos, de instituições e de pesquisas com a metodologia da história oral, abriu-se espaço para a integração das fontes orais aos acervos museológicos, embora se tenha de admitir, com certa relutância, tendo em vista o foco dos museus centrar-se na cultura material. No caso do Projeto Memória Lassalista, a circunstancialidade da sua constituição apoiou-se em intencionalidades, atos de vontade e redes de poder institucionais. $\mathrm{O}$ acervo, constituído por rastros, falas sobre o passado, organiza memórias que traduzem relações afetivas, bem como escolhas permeadas por valores do que deveria ser dito e não dito. A musealização do acervo dos testemunhos orais implica a imputação a eles, de herança cultural a ser preservada e a cada pesquisa e ou renovação, novos significados lhes são atribuídos.

Fez-se uma escolha ao criar e desenvolver o Projeto Memória Lassalista no âmbito do MAHLS, com o engajamento de salvaguardar e dar acesso a acervos escolares e narrar a educação e escolas lassalistas e, por consequência, contribuir para o campo da história da educação. Agora e no futuro, a intenção é de dar prosseguimento e consolidar o trabalho, criando novos projetos a partir de profunda reflexão teórica e metodológica, a fim de acompanhar os rumos dos estudos nos campos da memória social, da história da educação e da história oral. 


\section{Referências}

ALBERTI, Verena. Manual de História Oral. Rio de Janeiro: FGV Editora, 2004.

BELLOTTO, Heloísa Liberalli. Arquivos permanentes: tratamento documental. São Paulo: T.A. Queiroz, 1991.

BENJAMIN, Walter. Sobre o conceito de história. In: Magia e técnica, arte e política: ensaios sobre literatura e história da cultura. Trad. Sérgio Paulo Rouanet. São Paulo: Brasiliense, 1994. (Obras escolhidas; v. 1)

BOSI, Ecléa. Memória e Sociedade: lembranças de velhos. $3^{a}$. ed., São Paulo: Cia das Letras, 1994.

BOSI, Eclea. Tempo vivo da memória. São Paulo: Ateliê, 2003.

BROWN, Penélope; LEVINSON, Stephen C. Politeness some universals in language usage. London: Cambridge, 1987.

BRUCK, Mozahir Salomão. Entrevista com Profa. Eclea Bosi. Memória: enraizar-se é um direito fundamental do ser humano. Dispositiva, v. 1, n. 2, p. 196-199, 2012. Disponível em <http://periodicos.pucminas.br/index.php/dispositiva/article/view/4301> Acesso em janeiro/2015.

CANDAU, Joël. Bases antropológicas e expressões mundanas da busca patrimonial: memória, tradição e identidade. Memória em Rede, Pelotas, v.1, n.1, jan./jul. 2009, p. 43 58. Disponível em <http://asmic.unice.fr/PDF/candau-article-10.pdf $>$ Acesso em jul./2012.

CARVAlHO, Ana. Os Museus e o Património Cultural Imaterial: Estratégias para o Desenvolvimento de Boas Práticas. Lisboa: Edições Colibri e CIDEHUS-Universidade de Évora, 2011.

CORREAA, Carlos Humberto Pederneiras. História Oral: Teoria e Técnica. Florianópolis: UFSC, 1978.

COSTA, Icléia Thiesen Magalhães. Memória Institucional: a reconstrução conceitual numa abordagem teórica-metodológica. Tese de Doutorado. Programa de Pós-Graduação em Ciência da Informação. Universidade Federal do Rio de Janeiro. Rio de janeiro, 1997. Disponível em $<$ http://tede-dep.ibict.br/bitstream/tde/39/1/icleiacosta1997.pdf $>$ Acesso em janeiro de 2015.

DODEBEI, Vera. Memória, circunstância e movimento. In GONDAR, Jô; DEDEBEI, Vera (orgs.). O que é memória social? Rio de Janeiro: Contra Capa/PPGMS Unirio, 2005, p. $43-54$. 
DODEBEI, Vera. Patrimônio digital virtual: Herança, documento e informação, s/d. Disponível em <http://www.abant.org.br/conteudo/ANAIS/CD_Virtual_26_RBA/grupos_ de_trabalho/trabalhos/GT\%2037/vera\%20dodeber.pdf $>$ Acesso em janeiro/2016.

FALCON, Francisco José Calazans. História cultural e história da educação. Revista Brasileira de Educação, v. 11, n. 32, p. 328-339, 2006. Disponível em $<$ http://www.scielo.br/pdf/rbedu/v11n32/a11v11n32.pdf > Acesso em Fevereiro de 2015

FERREIRA, Marieta de Moraes (org). História Oral e Multidisciplinaridade. Rio de Janeiro: Diadorim, 1994.

FERREIRA, Marieta de Moraes. História, tempo presente e história oral. Topoi, Rio de Janeiro, dezembro 2002, pp. 314-332. Disponível em <http://revistatopoi.org/numeros anteriores/topoi05/topoi5a13.pdf $>$ Acesso em janeiro/2014.

FRANCO, Sérgio da Costa. Guia Histórico de Porto Alegre. 4. ed. Porto Alegre: Editora UFRGS, 2006.

GATTI JUNIOR, Décio. A história das instituições educacionais: inovações paradigmáticas e temáticas. In ARAÚJO, José Carlos Souza; GATTI JUNIOR, Décio (Org.). Novos temas em historia da educação brasileira: instituições escolares e educação na imprensa. Campinas: Autores Associados; Uberlândia/ MG: EDUFU, 2002. p. 3-24.

GOFFMAN, Erving. A representação do eu na vida cotidiana. Trad. Maria Célia Santos Raposo. Petrópolis: Vozes, 1985.

GONDAR, Jô. Quatro proposições sobre memória social. In GONDAR, Jô; DEDEBEI, Vera (orgs.). O que é memória social? Rio de Janeiro: Contra Capa/PPGMS Unirio, 2005, p. 11-26.

GOODSON, Ivor F. Dar voz ao professor: as histórias de vida do professor e o seu desenvolvimento profissional. In: NÓVOA, A (Org.). Vidas de Professores. Porto: Porto Editora, 1992.

GRAEBIN, Cleusa Maria Gomes; ALMEIDA, Doris Bittencourt. Memórias de escola, patrimônio da educação: o Museu e Arquivo Histórico La Salle - MAHLS (2002-2014) História da Educação, v. 19, n. 47, set./dez, 2015, p. 1-6. Disponível em $<$ http://www.seer.ufrgs.br/index.php/asphe/article/view/57987> Acesso em janeiro/2016.

GRAZZIOTIN, Luciane Sgarbi S.; ALMEIDA, Dóris Bittencourt. Romagem do tempo e recantos da memória: reflexões metodológicas sobre História Oral. São Leopoldo: Oikos, 2012.

GUIMARÃES, Manoel Luiz Salgado. Expondo a História: imagens construindo o passado. In: __ _ RAMOS, Francisco Régis Lopes (Orgs.). Futuro do Pretérito: Escrita da História e História do Museu. Fortaleza: instituto Frei Tito de Alencar/Expressão Gráfica Editora, 2010, p. 34-49.

HALBWACHS, Maurice. Memória Coletiva. São Paulo: Revista dos Tribunais, 1990. 
JULIA, Dominique. A cultura escolar como objeto histórico. Revista Brasileira de História da Educação. Campinas, 2001, nº 1. p. 9-43.

JULIÃO, Letícia. Pesquisa Histórica no Museu. Cadernos de Diretrizes Museológicas. Disponível em <http:/www.cultura.mg.gov.br/arquivos/Museus/File/caderno-diretrizes/ cadernodiretrizes_quintaparte.pdf $>$ Acesso em janeiro/2016.

LE GOFF, Jacques. História e memória. Campinas, Editora da Unicamp, 2003.

MAGAlHÃES, Justino Pereira de. Tecendo nexos: história das instituições educativas. Bragança Paulista: Editora Universitária São Francisco, 2004.

MENESES, Ulpiano T. Bezerra de. O museu e a questão do conhecimento. In GUIMARÃES, Manoel Luiz Salgado; RAMOS, Francisco Régis Lopes (Orgs.). Futuro do Pretérito: Escrita da História e História do Museu. Fortaleza: instituto Frei Tito de Alencar/Expressão Gráfica Editora, 2010, p. 13-33.

NAGLE, Jorge. História da Educação Brasileira: problemas atuais. Em Aberto, Brasília, v.3, n.23, p.27-29, set./out. 1994.

NETO, André de Faria Pereira; MACHADO, Bárbara Araújo; MONTENEGRO, Antonio Torres. História Oral no Brasil: uma análise da produção recente (1998/2008). História Oral (Rio de Janeiro), v.10, n.2, p. 113-126, 2009. Disponível em $<$ http://revista.historiaoral.org.br/index.php?journal=rho\&page=article\&op=view\&path $\% 5$ $\mathrm{B} \% 5 \mathrm{D}=219 \&$ path $\% 5 \mathrm{~B} \% 5 \mathrm{D}=223>$ Acesso em março/2015.

NETTO, Rodrigo de Sá; STAMPA, Inez Terezinha (Org). Arquivos da Repressão e da Resistência. Comunicações do I Seminário Internacional Documentar a Ditadura. Rio de Janeiro: Arquivo Nacional, 2013. Disponível em <http:/www.an.gov.br/seminario/ imagens/Arquivos $\% 20 \mathrm{da} \% 20$ Repress $\%$ E3o\%20e\%20da $\% 20$ Resist $\%$ EAncia.pdf $>$ Acesso em fevereiro/2014.

NÓVOA, A (Org.). Vidas de Professores. Porto: Porto Editora, 1992.

NÓVOA, A. Para uma análise das instituições escolares. In: . (Coord.). As organizações escolares em análise. Lisboa: Publicações Dom Quixote: IIE, 1992, p. 13-43.

NÓVOA, António. História da educação: percursos de uma disciplina. Análise Psicológica, Lisboa, n. 4, 1996, p. 417-434.

NUNES, Clarice; CARVALHO, Marta Maria Chagas de. Historiografia da educação e fontes. Cadernos Anped, Porto Alegre, n. 5, set. 1993.

OLIVEIRA, Valeska Fortes. Educação, memória e histórias de vida: usos da história oral. História Oral, Recife, v. 8, n. 1, p. 92-106. jan./jun. 2005. Disponível em $<$ http://revista.historiaoral.org.br/index.php?journal=rho\&page=article\&op=view\&path $\% 5$ $\mathrm{B} \% 5 \mathrm{D}=118 \&$ path $\% 5 \mathrm{~B} \% 5 \mathrm{D}=114>$ Acesso em 12/06/2011.

PATRIMÔNIO Imaterial. Disponível em <http://portal.iphan.gov.br/pagina/detalhes/234> Acesso em setembro/2015. 
POLLAK, Michel. Memória e identidade social. Estudos Históricos, Rio de Janeiro, v.5 n. 10 (1992), p. 200-212. Disponível em <http://bibliotecadigital.fgv.br/ojs/index.php/ reh/article/view/1941/1080> Acesso em janeiro/2010.

POLLAK, Michel. Memória, Esquecimento, Silencio. Estudos Históricos, Rio de Janeiro, vol. 2, n. 3, 1989, p. 3-15. Disponível em <http://www.uel.br/cch/cdph/arqtxt/Memoria _esquecimento_silencio.pdf $>$ Acesso em 15/02/2010.

PORTELLI, Alessandro. O que faz a história oral diferente. Projeto História. São Paulo, n.14, 1997, p. 7-24.

RAMOS, Francisco Régis Lopes. As utilidades do passado na biografia dos objetos. In: GUIMARÃES, Manoel Luiz Salgado; RAMOS, Francisco Régis Lopes (Orgs.). Futuro do Pretérito: Escrita da História e História do Museu. Fortaleza: instituto Frei Tito de Alencar/Expressão Gráfica Editora, 2010, p. 50-77.

RICOEUR, Paul. A marca do passado. História da historiografia, Ouro Preto, n. 10, dezembro, 2012, p. 329-349. Disponível em <www.historiadahistoriografia.com.br/revista/ article/download/456/335> Acesso em janeiro/2014.

RICOEUR, Paul. O esquecimento. In: . A memória, a história, o esquecimento. Campinas, SP: Unicamp, 2007. p. 123-462.

RICOEUR, Paul. Tempo e narrativa. Tomo III. Tradução Roberto Leal Ferreira. São Paulo: Papirus, 1997.

RIOUX, Jean-Pierre; SIRINELLI, Jean-François. Pour une histoire culturelle. Paris: Seuil, 1997.

SANTHIAGO, Ricardo. Carlos Humberto Pederneiras Corrêa, um pioneiro da história oral no Brasil. História Oral, v. 18, n. 1, p. 221-239, jan./jun. 2015. Disponível em $<$ http://www.revista.historiaoral.org.br/index.php?journal=rho\&page=article\&op=downloa d\&path $\% 5 B \% 5 \mathrm{D}=530 \&$ path $\% 5 \mathrm{~B} \% 5 \mathrm{D}=402>$ Acesso em novembro/2015.

SANTOS, Sônia Maria dos; ARAÚJO, Osmar Ribeiro de. História oral: vozes, narrativas e textos. Cadernos de História da Educação, n. 6, jan./dez. 2007. Disponível em: $<$ http://www.seer.ufu.br/index.php/che/article/view/282> Acesso em 12/06/2016.

SARMENTO, M. J. Lógicas de acção nas escolas. Lisboa: Instituto de Inovação Educacional, 2000.

SAVIANI, Dermeval. O debate teórico e metodológico no campo da história e sua importância para a pesquisa educacional. In: SAVIANI, Dermeval; LOMBARDI, José C.; SANFELICE, José L. (Orgs.) História e história da educação: o debate teóricometodológico atual. Campinas: Autores Associados/HISTEDBR, 1998, p. 7-15. 
SCHÜTZ, Karla Simone Willemann. Fábrica de memórias: o Laboratório de História Oral da UFSC durante o regime militar. Anais do XV Encontro Estadual de História - 19642014: Memórias, Testemunhos e Estado ,11 a 14 de agosto de 2014, UFSC, Florianópolis. Disponível em <http://docplayer.com.br/3257709-Fabrica-de-memorias-o-laboratorio-dehistoria-oral-da-ufsc-durante-o-regime-militar.html> Acesso em novembro/2015.

SZYMANSKI, Heloisa e outras. Perspectiva para an lise de entrevistas. In: SZYMANSKI, Heloisa (org.). A entrevista na pesquisa em educação: a prática reflexiva. Brasìlia: Plano, 2002.

TRACY, Karen; BARATZ, Sheryl. The case for case studies of facework. In: TINGTOOMEY (Org.). The challenge of facework. New York: State University of New York Press, 1994.

WARDE, Miriam Jorge. Contribuições da história para a educação. Em Aberto, Brasília: INEP/MEC, ano 9, n. 47, p. 3-11, jul./set.1990. Disponível em $<$ http://emaberto.inep.gov.br/index.php/emaberto/article/view/1779> Acesso em janeiro/2014.

WARDE, Mirian Jorge. Anotações para uma Historiografia da Educação Brasileira. Em Aberto, ano 3, n.23, set./out. 1984.

WERLE, Flávia Obino Corrêa. História das instituições escolares: Responsabilidade do gestor escolar. Cadernos de História da Educação, n. 3, jan./dez. 2004. Disponível em $<$ www.seer.ufu.br/index.php/che/article/download/369/357> Acesso em agosto/2015. 